\title{
LAND SUITABILITY MODELING FOR RICECROP BASED ON AN INTEGRATED MULTI-CRITERIA DECISION MAKING IN QUANG TRI PROVINCE OF VIETNAM
}

\author{
Thi Hanh Tong' ${ }^{1}$, Mai Phuong Pham ${ }^{2 *}$, Thi Quyen Bui ${ }^{3 *}$, Thi Mai Huong Nguyen ${ }^{4}$, Thi Thu Nga Nguyen ${ }^{1}$, \\ Alexander E. Balakirev ${ }^{2,5}$, Altaf Hussain Lahori ${ }^{6}$ \\ ${ }^{1}$ Le Quy Don Technical University, Bac Tu Liem District, Ha Noi City, Vietnam \\ Vietnam-Russia Tropical Centre, Cau Giay District, Hanoi, Vietnam \\ ${ }^{3}$ School of Business Administration, VNU University of Economics and Business, Cau Giay District, Hanoi, Vietnam \\ ${ }^{4}$ Vietnam National University of Forestry, Chuong My District, Ha Noi, Vietnam \\ ${ }^{5}$ A.N. Severtsov Institute of Ecology and Evolution, Russian Academy of Sciences, Leninskii pr. 33, Moscow 119071, \\ Russia \\ ${ }^{6}$ Department of Environmental Sciences, Sindh Madressatul Islam University, Karachi, Pakistan \\ *Corresponding author: phamphuong911vh@gmail.com; buiquyen@vnu.edu.vn
}

Received: February 22 $2^{\text {th }}, 2020$ / Accepted: August 2nd 2021 / Published: October 1st, 2021

https://DOI-10.24057/2071-9388-2021-017

\begin{abstract}
The present study was aimed to determine the potential cultivated lands for rice crop production in Vietnam. Analytic Hierarchy Process (AHP) and the Technique for Order of Preference by Similarity to Ideal Solution (TOPSIS) were employed in order to analyze the structure of an ideal solution in agriculture that focuses mainly on environmental, economic, and social sustainability. A final ranking of alternative development solutions was also accomplished. Three major factors were taken into consideration during the process, including the economics, social concerns, and the environment, in order to develop a sustainable plan for rice and other grain crops in the future. The obtained results demonstrate that the area under investigation in Quang Tri province, which encompasses $192.49 \mathrm{~km}^{2}$ of land area, was extremely conducive to growing rice crops, with the majority of the arable lands suitable for cultivating rice varieties concentrated in Trieu Long District (63.14 km²) and Hai Lang District $\left(56.87 \mathrm{~km}^{2}\right.$ ). The main findings of the present work indicated that, it can link decision makers with the influencing variables of rice crop growing utilizing a hybrid method that can be successfully used based on GIS technique. To expand production, chemical soil characteristics and agricultural development strategies should be investigated further, particularly in the studied areas with greater success potential.
\end{abstract}

KEYWORDS: Evaluation, GIS, AHP, land suitability, rice crop, TOPSIS

CITATION: Thi Hanh Tong, Mai Phuong Pham, Thi Quyen Bui, Thi Mai Huong Nguyen, Thi Thu Nga Nguyen, Alexander E. Balakirev, Altaf Hussain Lahori (2021). Land Suitability Modeling For Ricecrop Based On An Integrated Multi-Criteria Decision Making In Quang Tri Province Of Vietnam. Geography, Environment, Sustainability, Vol.14, No 3, p. 63-72

https://DOI-10.24057/2071-9388-2021-017

ACKNOWLEDGMENTS: We would like to express our deepest appreciation and sincere gratitude to all experts, communal authorities, local people in Quang Tri province who were wholeheartedly dedicated and collaborative throughout the period of this research and during the completion of the questionnaire and within discussions. Without the invaluable support of above mentioned individuals and organizations, this research would not have been possible. This study was proudly supported by Vietnam - Russia Tropical Center, project E 1.2.

Conflict of interests: The authors reported no potential conflict of interest.

\section{INTRODUCTION}

During the period from 2008 to 2017, the GDP growth rate of the entire agricultural sector of Vietnam reached a striking average of $2.66 \%$ per year with the rate of 2018 hitting a record figure of 3.76\%. In 2019, despite many hurdles, Vietnamese agriculture continued to maintain its growth momentum of 2.2\% (Ministry of agriculture and rural development 2019).

Rapid urbanization and urban expansion have resulted in the inevitable depletion of agricultural land resources leading to reduced rice-crop growing areas. An integrated approach to improving the ability to increase rice-crop productivity is needed for planning of land resources (Quang Tri Provincial Committee 2020).

The geographic information system (GIS) provides the necessary support for management and the analysis of large volumes of data concerning complex geography (Stefanidis 2009; Tang 2009; Jamil 2018). The analytic hierarchy process (AHP) has been increasingly applied as a technique for multi-criteria decision analysis in multipurpose tasks (Stefanidis et al. 2013; Akıncı et al. 2013; Bagheri et al. 2013; Jiuquan et al. 2015; Kazemi 2016; Estrada et al. 2017; Seyedmohammadi et al. 2019). It can 
support the decision-making process to arrive at a decision that the panel members trust. Disagreements in judgments can indicate, that the judgments can be adapted until the group members are satisfied with the decision outcomes (Hummel et al. 2014).

Over the last decade, a large number of studies, researches, institutes and projects have been carried out in an attempt to construct a comprehensive procedure for the optimal use of agricultural land (Jeffrey et al. 2009). Multiple criteria decision analysis (MCDA) has been considered the high feasible technique for solving complicated issues. MCDA techniques, such as analytic hierarchy process (AHP) based on GIS, is an effective framework to assess for the strategic placement of cropping (Seyedmohammadi et al. 2019). Many years ago, GIS-based research was carried out to develop new arable lands for the cultivation of rice and other crops in efforts of environmental conservation and efficient management of natural resources, which was proved essential for ensuring adequate food supplies and sustainability in agricultural development (Dengiz et al. 2013; Al-Yamani et al. 2013). The application of GIS and multi-indicator assessment techniques in land adaptation assessment have captivated numerous scientists the world over (Rahmanipour et al. 2014). There has been an urgent need to apply the principles of sustainable production to land resources and land use and to meet the requirements of society while conserving fragile ecosystems (FAO 1993). The potential and limitations of land usage for plant production were predicted through assessment of land suitability for cultivation in Azadshahr Township - Iran, utilizing an analytic hierarchy process (AHP). This study provides a special methodological approach to evaluation of suitable areas that can appear useful for decision makers and farmers to adopt as a planning (Maleki et al. 2017). AHP is becoming more and more utilitarian in agricultural planning. Vietnam located in tropical climatic zone and is evident to have had favorable conditions to grow agricultural products in various locations, including lowlands, mountainous areas, highland, and even coastal ecological sub-regions. Vietnam's agricultural productivity has invariably maintained an average annual growth rate of approximately 3.5\%, translating to one of the most significant proportions among all Asian countries in general. After a prolonged period of food scarcity since 1989, Vietnam has, since then, gradually become the world's rice export powerhouse.
In Vietnam, initial research on applying GIS to land adaptive assessment was carried out in the 90s of the twentieth century. Studies have used GIS technology in zoning for either the adaptability or adaptation to land use types based on GIS application and MCA multi-standard analysis method in the AHP - IDM technique. Today, GIS and AHP technique have been proven effective for their application in agricultural production planning (Vy et al. 2014; Huynh et al. 2015; Chau et al. 2017; Dieu et al. 2107; Huynh et al. 2015).

Quang Tri is a region requiring an outsized amount of attention due to its outdated agriculture practices and low urbanization rate. Rice and crops are the major agricultural product in Quang Tri province (Quang Tri Statistical Office 2019). The needs for optimal land usage are of pivotal important here in due to various complicated social aspects and a broadly low domestic product in this province. Assessment of suitable land is therefore rendered largely necessary for rational management of land use in future planning. The present study is a novel, which focuses on the potential cultivated lands for rice crop production using Analytic Hierarchy Process (AHP) and Technique for Order of Preference by Similarity to Ideal Solution (TOPSIS) aiming to analyzed in agriculture based on environmental, economic, and social sustainability. This study was aimed to modeling the land suitability for rice and crops affecting province's ecological assets. The majority of these criteria have to be evaluated by linguistic terms rather than numerical values (Suder and Kahraman 2018).

\section{MATERIALS AND METHODS}

\section{Study area}

A humid tropical climate, typical of the inner tropical ring of the Northern Hemisphere, prevails in Quang Tri, which receives significant influence from the sea. Mountains, hills, plains, sand dunes, and beaches make up the diverse topography, which is positioned in a northwest-southeast orientation and comprises primarily of mountains and hills. Mountainous landscape with altitudes ranging from 250 to 2000 meters. The landscape has been extremely dissected, with steep hills on all sides. The landscape is hilly, with altitudes varying from 50 to 250 meters above sea level (Fig. 1). Several crops, including rice, sweet potatoes, pineapple, soy beans, groundnuts, and melons, contribute to the province's economic well-being.

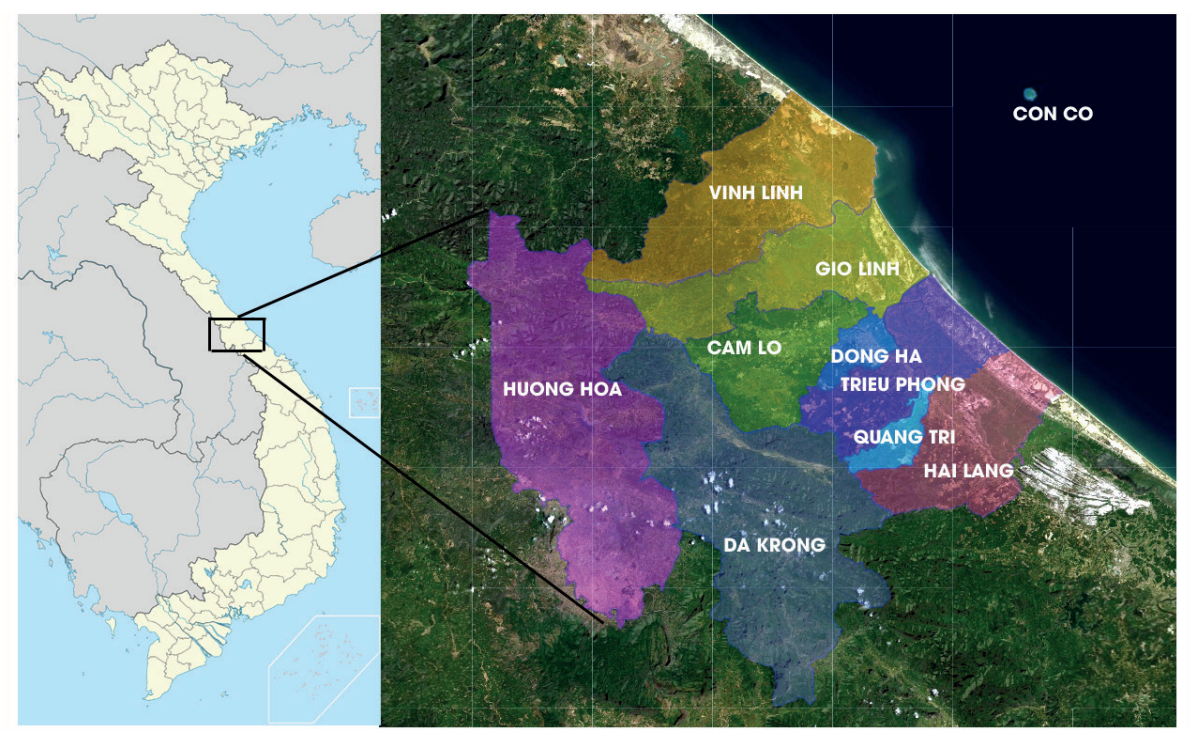

Fig. 1. Location map of study area

Source: Map background is taken from Open Street Map (OSM), Arcgisonline, Google Map, Wmflabs... Administrative boundary data is compiled from Database of Global Administrative Areas, Global Map of Vietnam CISCGM, Ministry of Natural Resources and Environment - Vietnam 


\section{MATERIAL}

The climate data was gathered from three weather stations located within the study province and its neighboring areas. The climatic means were calculated based on data from period of 2000-2008 years. The mapping of the climatic variables was completed with the help of the ArcGIS 10.0 program. During a survey conducted in April 2020, soil samples from 120 profiles around the province were gathered at random. Maps showing the geographical distribution of soil depth and waterlogging were created for the study provincial region. Vietnam's National Soil Maps (2010), which were used in the research, were acquired from the Ministry of Natural Resources and Environment's website. The elevation layer was obtained from the website (http://srtm.csi.cgiar.org/). With the help of ArcGIS 10.0, we were able to calculate the slope from the DEM (resolution $30 \times 30 \mathrm{~m}$ ). It was possible to get land use data from Ministry of Natural Resources and Environment (MONRE, 2015), which contained presently rice-crop land that was gathered utilizing remote sensing images taken during the wet and dry seasons. These previously mentioned statistics were incorporated into the model in order to map the suitability of land for producing rice crops.

\section{METHODOLOGY}

\section{Identification of criteria}

Two groups of experts were designed as follows: Group work N01 (GW1) was organized with members of the provincial local authorities and a research team to determine criteria that include environmental, economic, and social conditions influencing rice and crop land suitability. Upon discussions, criteria had been selected and included in questionnaire sent to committee (to 5 decision-makers: $D_{1}, D_{2}, \ldots, D_{5}$ ). The purpose of this work was to rank possible site alternatives $(A 1, A 2, \ldots, A 10)$ in the Quang Tri province for an ideal solution. This model used the TOPSIS method, which used multi-criteria from C1, C2,..., C9 (Fig. 2, Table 3).

Group work N02 (GW2) was comprised of 10 members. Among these, there were 5 local experts and 5 local farmers who joined the council to determine the criteria for the natural conditions influencing the rice crop growth. Upon discussion, criteria were selected and included in the questionnaire, then delivered to the aforementioned experts and local farmers. The goal of this work is to weigh the criteria. Each criterion is categorized into four levels (S1, $\mathrm{S} 2, \mathrm{~S} 3, \mathrm{~N}$ ) based on the ecological requirements of rice crop cultivation of the Instruction for agricultural production land evaluation of Vietnamese Standard ISO (8409:2012).
The integration of AHP-GIS was used in this model. This approach may be graphically formulated as follows (Fig. 2, Table 9).

The results of two teams of researchers (GW1 and GW2) were explored in detail discussion.

\section{The Technique for Order of Preference by Similarity to Ideal Solution (TOPSIS)}

Step 1: Construct a set of criteria for evaluating rice-growing areas in Quang Tri. The information utilized in this study was gathered through in-depth interviews with members of the decision-making and site-selection committees. Following the decision-making process, criteria for evaluating the rice growing location in Quang Tri were established.

Step 2: Determine the relative importance of each criterion. Using a metaphor, each individual decision-making committee (D1, D2, D3, D4, D5) evaluates the significance of a set of evaluation criteria after creating a set of assessment criteria. The weights assigned to each standard were established.

Step 3: Calculate the average proportion of alternatives available based on each of the criteria. During this stage, the decision-making committee will consider each site (A1, A2, A3, $A 4, A 5, A 6, A 7, A 8, A 9$, and $A 10)$ in agreement with the set of criteria that has been determined before. In agreement with each criterion, the decision-making council evaluated the rating scale and significance size of each site. Applying the formula in Eq. (1):

$$
x_{i j}=\frac{1}{k} \times\left(x_{i j 1}+x_{i j 2}+\ldots+x_{i j t}+\ldots+x_{i j k}\right)
$$

Step 4: Calculate the weighted average of the results. The fuzzy-decision matrix with weights and normalization should be calculated. by formula in Eq. (2):

$$
w_{j}=\frac{1}{k} \times\left(w_{j 1}+w_{j 2}+\ldots+w_{j k}\right)
$$

Step 5: Standardize the way in which alternatives are presented in relation to objective criteria. The result of the evaluation stage was used to obtain at the normalized values of choice Dt with respect to each criteria Cj for each $\mathrm{Ai}$ in this step.

Step 6: Calculate the value of the normalized standard in given case. The normalized scoring weight value $\mathrm{Gi}$ is obtained by multiplying the weight values of the criterion by the normalized rating weight value Gi. Formula in Eq. (3):

$$
G_{j}=x_{i j} \times w_{j}, i=1, \ldots, m, j=1, \ldots, n
$$

Step 7: Calculate The optimal fuzzy positive ideal solution A + and the optimal fuzzy negative ideal solution A- are selected (Table 1).

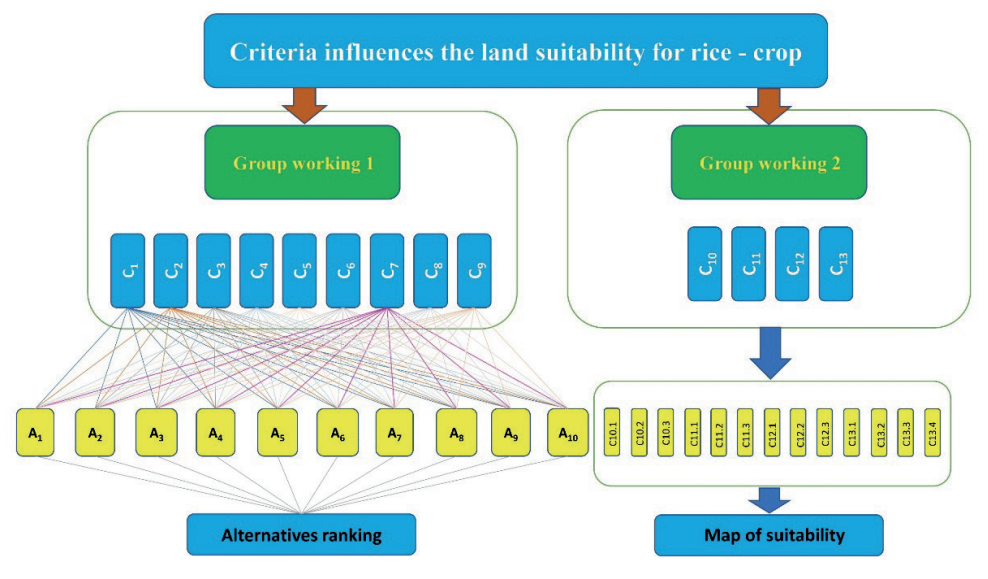

Fig. 2. The study process analysis 
Table 1. Optimal dimming solution

\begin{tabular}{|c|c|c|c|}
\hline At & 1 & 1 & 1 \\
\hline$A-$ & 0 & 0 & 0 \\
\hline
\end{tabular}

Step 8. Calculate the distance between each solution as well as the coefficients in close proximity by formula in Eq. (4):

$$
\begin{aligned}
& d_{i}^{+}=\sqrt{\sum_{j=1}^{n}\left(G_{i}-A^{+}\right)^{2}} \\
& d_{i}^{-}=\sqrt{\sum_{j=1}^{n}\left(G_{i}-A^{-}\right)^{2}}
\end{aligned}
$$

The closeness coefficient (CCi) is used to evaluate which alternatives should be favoured in the ranking process. Formula in Eq. (5):

$$
C C_{i}=\frac{d_{i}^{-}}{d_{i}^{+}+d_{i}^{-}}
$$

Step 9: Determine the order in which alternatives should be ranked based on respective coefficients. This was the last step in the process of evaluating the alternatives. The best alternative sites have the highest closeness coefficients, while the worst alternative sites are the furthest away from the positive ideal solution and the closest to the negative ideal solution in terms of distance and closeness coefficients.

\section{Analytic hierarchy process (AHP)}

A credit scoring model based on this expert judgement can be developed using a technique of analytic hierarchy process (AHP). For this type of model, the validation requirement can be problematic. The judgments made then converted into a scale of 1 to 9 that reflected the relative importance of one element over others in relation to attribute of the element in query (Saaty 2008; Saardchom 2012; Hummel et al. 2014; Table 2) In order to determine which criteria affect to land-use suitability for rice and crops, ten experts are invited to process to provide judgments on pair comparison question, which assisted in the determination of the importance of each criteria of natural conditions. Overall, priorities can be made through synthesising or pooling together the judgement made in the pairwise comparisons (Saardchom 2012). Consistency Ratio (CR) (< $10 \%$ ) was used to check the accuracy of comparisons (Malczewski 1999; Saaty 2000; Saardchom 2012; Bozdağ 2016; Maleki 2017).

Score for each criterion $\left(X_{j}^{\prime \prime}\right)$ on each land mapping unit was determined, importance of criteria $i^{\prime}$ are converted to criteria weights $\left(W_{i}^{\prime \prime}\right)$, in which $i^{\prime}$ rang from 1 to $m$, where $m$ was the total number of criteria involved in the process. The weighted linear combination of $\mathrm{W}^{\prime \prime}$ and $X_{i}^{\prime \prime}$ give suitability index (SI) for each land mapping unit (LMU). By above process, land-use suitability map is produced. Score of each level criterion is computed for each LMU. These values are combined with the above mentioned overall weight to provide suitability value for each LMU corresponding to each land-use type. This process was done in ArcGlS through the composite map of land mapping units using the formula in Eq (6).

$$
S I=\sum_{i^{\prime}=1}^{m}\left(W_{i^{\prime}}, X_{i^{\prime}}\right)
$$

According to the FAO (1993), the most suitable index was SI, (with a value > 80\%), followed by SI, (40\%-80\%), which was a moderately suitable index, and then $\mathrm{SI}_{3}$ (20\%-40\%), which was a marginally suitable index, and finally $N$ (with a value less than 20\%), which was not a suitable index.

\section{Geographic Information System (GIS)}

To estimate an appropriate piece of land, utilize aggregated values of inputs and weights. GIS and AHP were demonstrated in an evaluation of land suitability. The approach was originally designed as a logically and systemically quantitative framework, in which priorities are set, options are selected, and a connection is made with other participants. GIS technique was used to increase geographic fuzzy decision making. Using the structured AHP, expert perspectives are applied to establish the weights of given criteria. TOPSIS weights the potential for rice cultivation on the land to generate a ranking. GIS is used to run the Spatial Analyst module, and it is also used to determine suitability variables. This technique led to the assessment structure in Figure 3, 6. A questionnaire was used to gather information on importance of each criterion from local experts. Specifically, the goal of this study is to produce 13 component maps in raster format. All raster layers were targeted at WGS84-Zone 48N, and the AHP algorithm, which collected weights for all criteria, was used to apply the weights to the layers. The appropriateness of land for rice cultivation was determined by overlaying (superimposing) 13 raster component maps, which were created using ArcGIS 10.0 software. The map of land suitable for rice crops was finally obtained and categorized into four groups based on its classification (SI1, SI2, SI3, N).

\section{Table 2. Nine-point scale using in AHP}

\begin{tabular}{|c|c|}
\hline Intensity of importance & Judgments of verbal attribute labels \\
\hline 9 & Absolute importance \\
\hline 7 & Very strongly importance or preferred \\
\hline 5 & Strong importance or strongly preferred \\
\hline 3 & Weak importance, moderately important or preferred \\
\hline $2,4,6,8$ & Intermediate values between adjacent judgments of two \\
\hline 1 & Equally preferred more important or preferred \\
\hline
\end{tabular}

Source: Saaty 2008 


\section{RESULTS AND DISCUSSION}

Evaluation of land suitability from the Group Working $N^{0} 1$ (GW1)

The factors influencing rice crop growth were determined using data from detailed interviews with committee members (D1, D2, D3, D4, D5).Table 3 displayed nine criteria that were pointed out by the council, including: Income from rice crop production $\left(C_{1}\right)$, Rate of return from rice crop production $\left(C_{2}\right)$, Local policy $\left(C_{3}\right)$, Financial resources $\left(C_{4}\right)$, Farmer skills $\left(C_{5}\right)$, Farming habits $\left(C_{6}\right)$, Labor force $\left(C_{7}\right)$, Technology improves rice production $\left(C_{8}\right)$, Natural condition $\left(C_{0}\right)$.

The regions included in the assessment are $\mathrm{A}_{1}$ : Dong $\mathrm{Ha}$ City, $\mathrm{A}_{2}$ : Quang Tri Town, $A_{3}$ : Vinh Linh district, $A_{4}$ : Huong Hoa district, $A_{5}$ : Gio Linh district, $A_{6}$ : Dakrong district, $A_{7}$ : Cam Lo district, $A_{8}$ : Trieu Phong district, $A_{9}$ : Hai Lang district, $A_{1}$ : Con Co district. Table 3 shows the data obtained from discussions with committee members (D1, D2,..., D5) to determine the factors affecting rice growing.Three major criteria for this assessment were: economic sustainability, social sustainability and environmental sustainability. Nine sub-criteria were choiced to involved in the model. Table 4 shows the weights of the standards $\left(\mathrm{Cl}_{1}, \mathrm{C}_{1} \ldots, \mathrm{C} 9\right)$. Opinion of decision maker Dt on criterion $\mathrm{Ci}$ is $\mathrm{El}$ is mean Ci is extremely important criterion than other, or $\mathrm{Ml}$ is mean $\mathrm{Ci}$ is medium important one compared to others. This results also reveal that fuzzy set theory (Zadeh 1965) allows decision-makers to incorporate unquantifiable information and non-obtainable information into the model.
Table 5 shows the distance values of each option (A1, A2,..., A10) from the positive ideal and the negative ideal. The ultimate ranking of alternatives was decided by the closeness coefficients of the alternatives in question (CCi). The most suitable alternatives are those that are closest to the positive ideal. As measured by the closeness coefficient, the Hai Lang district rank was the highest for rice crops cultivation $\left(\mathrm{CC}_{(\mathrm{Ag})}:\right.$ 0.6354), followed by Trieu Phong $\left(C C_{(A B)}: 0.6150\right)$, and Gio Linh ( $\left.C C_{(A 5}: 0.6025\right)$. These are districts that are less suitable for rice crops cultivation such as: Con Co district (CC $_{(\mathrm{A} 10)}:$ 0.5426), followed by Dakrong district (CC $\left.{ }_{(\mathrm{A} 6)}: 0.5563\right)$, Quang Tri Town (CC $\left.{ }_{(A 2}: 0.5669\right)$, Huong Hoa district (CC $\left.{ }_{(A 4)}: 0.567\right)$, Dong Ha City (CC $\left.{ }_{(A)}: 0.5712\right)$.

\section{Evaluation of alternatives from the Group Working N²2 (GW2)}

The data from detailed interviews with 10 experts determined the factors effecting rice crop growing, Table 6 indicated that there were 4 main criteria obtained by council, which were: Soil $\left(C_{10}\right)$, topography $\left(C_{11}\right)$, hydrology $\left(C_{12}\right)$, climatic characteristics $\left(C_{13}^{10}\right) ; 13$ sub-criteria include: Soil type $\left(C_{10.1}\right)$, soil depth $\left(C_{10.2}\right)$, soil composition $\left(C_{103}\right)$, elevation $\left(C_{111}\right)$, slope $\left(C_{112}\right)$, terrain $\left(C_{113}\right)$, irrigation conditions $\left(C_{12} 1\right)$, flooding $\left(C_{122}\right)$, average annual rainfall $\left(C_{123}\right)$, average annual temperature $\left(C_{131}\right)$, annual maximum average temperature $\left(C_{132}\right)$, annual average minimum temperature $\left(C_{13.3}\right)$, number of sunny hours per month $\left(C_{13.4}\right)$.

\section{Table 3. Criteria involved in TOPSIS model}

\begin{tabular}{|c|c|c|}
\hline Criteria & Sub - Criteria & Definition \\
\hline \multirow{2}{*}{ Economic sustainability } & $\begin{array}{c}C_{1}: \text { Income from rice crop } \\
\text { production }\end{array}$ & $\begin{array}{l}\text { Income from rice crop production calculated by Vietnam (dong/ha } \\
\text { per year) }\end{array}$ \\
\hline & $\begin{array}{l}\mathrm{C}_{2}: \text { Rate of return from rice crop } \\
\text { production }\end{array}$ & The net gain or loss of an investment over a specified time period \\
\hline \multirow{5}{*}{ Society sustainability } & $C_{3}:$ Local policy & $\begin{array}{l}\text { Local policy is a principle that guides local farmers making decisions } \\
\text { result in positive outcomes enhance the living }\end{array}$ \\
\hline & $\mathrm{C}_{4}$ : Financial resources of household & Household capital may be ready for use in agricultural investment. \\
\hline & $C_{5}:$ Farmer skills & $\begin{array}{c}\text { Farmer skills are considered as the density of households who are } \\
\text { proficient in farming }\end{array}$ \\
\hline & $\mathrm{C}_{6}$ : Farming habits & The activity of working on a farm is ancient \\
\hline & $C_{7}:$ Labor force & Number of employees cultivating rice \\
\hline \multirow[b]{2}{*}{ Environmental sustainability } & $\mathrm{C}_{8}:$ Technology & Technology improves rice-crop production \\
\hline & $\mathrm{C}_{9}:$ Natural condition & $\begin{array}{l}\text { General assessment of the potential of land, climate and water } \\
\text { resources for rice production }\end{array}$ \\
\hline
\end{tabular}

Table 4. Decision matrix using Fuzzy linguistic variables

\begin{tabular}{|c|c|c|c|c|c|c|}
\hline & $\mathrm{D}_{1}$ & $\mathrm{D}_{2}$ & $\mathrm{D}_{3}$ & $\mathrm{D}_{4}$ & $\mathrm{D}_{5}$ & Wij \\
\hline$C_{1}$ & $\mathrm{El}$ & $\mathrm{El}$ & $\mathrm{El}$ & $\mathrm{El}$ & $\mathrm{Ml}$ & $(0.740,0.860,0.980)$ \\
\hline$C_{2}$ & $\mathrm{Ml}$ & $\mathrm{El}$ & $\mathrm{El}$ & $\mathrm{El}$ & $\mathrm{El}$ & $(0.680,0.860,0.980)$ \\
\hline$C_{3}$ & $\mathrm{El}$ & $\mathrm{El}$ & $\mathrm{El}$ & $\mathrm{Ml}$ & $\mathrm{El}$ & $(0.740,0.860,0.960)$ \\
\hline$C_{4}$ & $\mathrm{Ml}$ & $\mathrm{El}$ & $\mathrm{Ml}$ & $\mathrm{Ml}$ & $\mathrm{El}$ & $(0.620,0.780,0.920)$ \\
\hline$C_{5}$ & $\mathrm{Ml}$ & $\mathrm{Ml}$ & $\mathrm{Ml}$ & $\mathrm{Ml}$ & $\mathrm{Ml}$ & $(0.500,0.700,0.900)$ \\
\hline$C_{6}$ & $\mathrm{El}$ & $\mathrm{Ml}$ & $\mathrm{Ml}$ & $\mathrm{Ml}$ & $\mathrm{Ml}$ & $(0.560,0.700,0.900)$ \\
\hline $\mathrm{Cl}_{5}$ & $\mathrm{Ml}$ & $\mathrm{Ml}$ & $\mathrm{Ml}$ & $\mathrm{Ml}$ & $\mathrm{El}$ & $(0.560,0.740,0.920)$ \\
\hline $\mathrm{C} 8$ & $\mathrm{Ml}$ & $\mathrm{Ml}$ & $\mathrm{Ml}$ & $\mathrm{El}$ & $\mathrm{Ml}$ & $(0.560,0.740,0.940)$ \\
\hline $\mathrm{Cl} 9$ & $\mathrm{El}$ & $\mathrm{Ml}$ & $\mathrm{El}$ & $\mathrm{El}$ & $(0.740,0.860,1.000)$ \\
\hline
\end{tabular}


Table 5. The distance values and the final rankings

\begin{tabular}{|c|c|c|c|c|}
\hline Alternatives & $\begin{array}{c}\text { Separation from Positive } \\
\text { Ideal solution }\left(d^{+}\right)\end{array}$ & $\begin{array}{c}\text { Separation from } \\
\text { Negative ldeal solution } \\
(d)\end{array}$ & $\begin{array}{c}\text { Closeness Coefficient } \\
\text { (CCi) }\end{array}$ & Rank \\
\hline$A_{9}$ (Hai Lang district) & 0.6906 & 1.2038 & 0.6354 & 1 \\
\hline$A_{8}$ (Trieu Phong district) & 0.7498 & 1.1977 & 0.615 & 3 \\
\hline$A_{5}$ (Gio Linh district) & 0.7912 & 1.1993 & 0.6025 & 4 \\
\hline$A_{3}$ (Vinh Linh district) & 0.8172 & 1.2045 & 0.5737 & 5 \\
\hline$A_{7}$ (Cam Lo district) & 0.9087 & 1.223 & 0.5712 & 6 \\
\hline$A_{1}$ (Dong Ha City) & 0.9321 & 1.2416 & 0.567 & 7 \\
\hline$A_{4}$ (Huong Hoa district) & 0.9368 & 1.2269 & 0.5669 & 8 \\
\hline$A_{2}$ (Quang Tri Town) & 0.9436 & 1.2353 & 0.5563 & 9 \\
\hline$A_{6}$ (Dakrong district) & 0.9891 & 1.2399 & 0.5426 & 10 \\
\hline$A_{10}$ (Con Co district) & 1.0781 & 1.2787 & \\
\hline
\end{tabular}
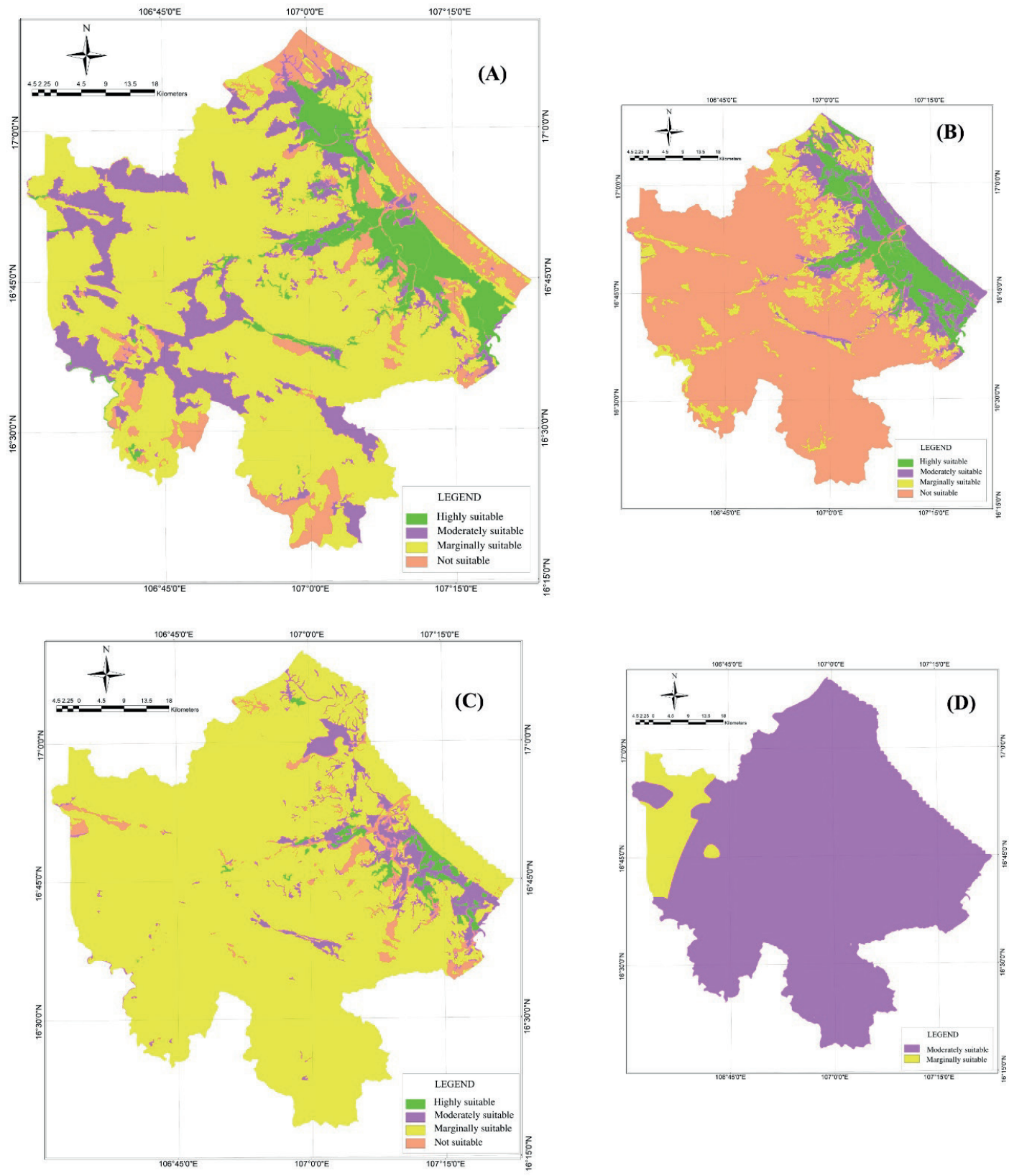

Fig. 3. Map of main criteria assessment for rice crops in Quang Tri province, Soil (A); Topography (B); Hydrology (C); Climatic 
Table 6. Criteria involved in model of integration of GIS and AHP

\begin{tabular}{|c|c|c|c|c|c|c|c|c|c|}
\hline \multirow[b]{2}{*}{ Criteria } & \multirow{2}{*}{$\begin{array}{l}\text { Weight } \\
\text { (W1) }\end{array}$} & \multirow[b]{2}{*}{$C R$} & \multirow[b]{2}{*}{ Sub - criteria } & \multirow{2}{*}{$\begin{array}{l}\text { Weight } \\
\text { (W2) }\end{array}$} & \multicolumn{4}{|c|}{ Category } & \multirow[b]{2}{*}{ Source } \\
\hline & & & & & $\begin{array}{l}\text { High suitable } \\
\left(\mathrm{S}_{1}\right)\end{array}$ & $\begin{array}{c}\text { Moderate } \\
\text { suitable }\left(\mathrm{S}_{2}\right)\end{array}$ & $\begin{array}{l}\text { Low suitable } \\
\qquad\left(\mathrm{S}_{3}\right)\end{array}$ & $\begin{array}{c}\text { Not suitable } \\
\text { (N) }\end{array}$ & \\
\hline \multirow{4}{*}{$C_{10}:$ Soil } & \multirow{4}{*}{0.399} & \multirow{4}{*}{0.0058} & $\begin{array}{l}\text { Soil type } \\
\text { group }\end{array}$ & 0.426 & $\begin{array}{c}\text { Podzols } \\
\text { (National soil } \\
\text { type: } \mathrm{Pb}, \mathrm{Pf} \\
\mathrm{Pg}, \mathrm{Pe} \text { ) }\end{array}$ & $\begin{array}{c}\text { Cambisols, } \\
\text { Ferralsols, } \\
\text { Podzoluvisols, } \\
\text { Reyzems } \\
\text { (National soil } \\
\text { type: B, Fl, Fp, } \\
\text { Mi, D, Py) }\end{array}$ & $\begin{array}{c}\text { Andosols, } \\
\text { Chernozems, } \\
\text { Xerosols } \\
\text { (National soil } \\
\text { type: Fj, Fq, Fs, } \\
\text { Fu,M, Mn, T, } \\
\text { C, X) }\end{array}$ & $\begin{array}{l}\text { Other soil } \\
\text { types }\end{array}$ & $\begin{array}{c}\text { FAO, 1974, } \\
\text { 1983, 1985, } \\
\text { Vietnamese } \\
\text { Standard ISO } \\
\text { 8409:2012 }\end{array}$ \\
\hline & & & $\begin{array}{l}\text { Soil depth } \\
\text { (cm) }\end{array}$ & 0.164 & $>100$ & $>70-100$ & $>30-70$ & $<30$ & Local farmer \\
\hline & & & Soil texture & 0.138 & $\begin{array}{l}\text { Loam, Clay } \\
\text { loam }\end{array}$ & $\begin{array}{l}\text { Sandy loam, } \\
\text { heavy clay } \\
\text { loam }\end{array}$ & Clay & Sandy & $\begin{array}{c}\text { Vietnamese } \\
\text { Standard ISO } \\
8409: 2012\end{array}$ \\
\hline & & & Fertilization & 0.272 & High & Moderate & Low & $\begin{array}{c}\text { Eroded soil } \\
\text { with bare } \\
\text { gravel, rocks, } \\
\text { rivers }\end{array}$ & Local farmer \\
\hline \multirow{3}{*}{$\begin{array}{c}C_{11}: \\
\text { Topography }\end{array}$} & \multirow{3}{*}{0.104} & \multirow{3}{*}{0.0027} & Elevation & 0.293 & $>3-10$ & $>10-20,<3$ & $>20-50$ & $>50$ & Local farmer \\
\hline & & & Slope $\left(^{0}\right)$ & 0.419 & $0-3$ & $>3-8$ & $>8-15$ & $>15$ & Local farmer \\
\hline & & & Terrain & 0.288 & Dune & High dune & Low dune & $\begin{array}{l}\text { Very low, } \\
\text { very high } \\
\text { dune }\end{array}$ & $\begin{array}{c}\text { Vietnamese } \\
\text { Standard ISO } \\
8409: 2012\end{array}$ \\
\hline \multirow{3}{*}{$\begin{array}{c}C_{12}: \\
\text { Hydrology }\end{array}$} & \multirow{3}{*}{0.408} & \multirow{3}{*}{0.0032} & $\begin{array}{l}\text { Irrigation } \\
\text { conditions }\end{array}$ & 0.523 & $\begin{array}{l}\text { Active } \\
\text { irrigation }\end{array}$ & & $\begin{array}{l}\text { Difficult } \\
\text { irrigation }\end{array}$ & Not irrigation & $\begin{array}{c}\text { Vietnamese } \\
\text { Standard ISO } \\
8409: 2012\end{array}$ \\
\hline & & & Flooding & 0.257 & Not inundated & & $\begin{array}{c}\text { Not } \\
\text { inundated }\end{array}$ & Rivers & Local farmer \\
\hline & & & $\begin{array}{c}\text { Average } \\
\text { annual } \\
\text { rainfall }(\mathrm{mm})\end{array}$ & 0.220 & $>2000-2500$ & $\begin{array}{c}>1500-2000 \\
>2500\end{array}$ & $>1300-1500$ & $<1300$ & $\begin{array}{c}\text { Vietnamese } \\
\text { Standard ISO } \\
8409: 2012\end{array}$ \\
\hline \multirow{4}{*}{$\begin{array}{c}C_{13} \\
\text { Climate }\end{array}$} & \multirow{4}{*}{0.089} & \multirow{4}{*}{0.0001} & $\begin{array}{c}\text { Average } \\
\text { annual } \\
\text { temperature }\end{array}$ & 0.222 & $>25-30\left({ }^{\circ} \mathrm{C}\right)$ & $>20-25\left({ }^{\circ} \mathrm{C}\right)$ & $\begin{array}{c}>30,>15-20 \\
\left({ }^{\circ} \mathrm{C}\right)\end{array}$ & $<15\left({ }^{\circ} \mathrm{C}\right)$ & $\begin{array}{c}\text { Vietnamese } \\
\text { Standard ISO } \\
8409: 2012\end{array}$ \\
\hline & & & $\begin{array}{l}\text { Annual } \\
\text { maximum } \\
\text { average } \\
\text { temperature }\end{array}$ & 0.188 & $>30-35\left({ }^{\circ} \mathrm{C}\right)$ & $>25-30\left({ }^{\circ} \mathrm{C}\right)$ & $\begin{array}{c}>20-25 ;>35 \\
\left({ }^{\circ} \mathrm{C}\right)\end{array}$ & $<20\left({ }^{\circ} \mathrm{C}\right)$ & $\begin{array}{c}\text { Vietnamese } \\
\text { Standard ISO } \\
8409: 2012\end{array}$ \\
\hline & & & $\begin{array}{c}\text { Annual } \\
\text { average } \\
\text { minimum } \\
\text { temperature }\end{array}$ & 0.188 & $>20-25\left({ }^{\circ} \mathrm{C}\right)$ & $>15-20\left({ }^{\circ} \mathrm{C}\right)$ & $\begin{array}{c}>10-15,>25 \\
\left({ }^{\circ} \mathrm{C}\right)\end{array}$ & $<10\left({ }^{\circ} \mathrm{C}\right)$ & $\begin{array}{c}\text { Vietnamese } \\
\text { Standard ISO } \\
8409: 2012\end{array}$ \\
\hline & & & $\begin{array}{l}\text { Number of } \\
\text { sunny hours } \\
\text { per month }\end{array}$ & 0.402 & $>200$ & $>150-200$ & $>100-150$ & $<100$ & $\begin{array}{c}\text { Vietnamese } \\
\text { Standard ISO } \\
8409: 2012\end{array}$ \\
\hline
\end{tabular}

Table 7. Suitable land as assessed by main criteria

\begin{tabular}{|c|c|c|c|c|c|c|c|c|}
\hline \multirow{2}{*}{ Category } & \multicolumn{2}{|c|}{ Soil } & \multicolumn{2}{|c|}{ Water } & \multicolumn{2}{c|}{ Topography } & \multicolumn{2}{c|}{ Climate } \\
\cline { 2 - 9 } & Area $\left(\mathrm{Km}^{2}\right)$ & Area $(\%)$ & Area $\left(\mathrm{Km}^{2}\right)$ & Area $(\%)$ & Area $\left(\mathrm{Km}^{2}\right)$ & Area $(\%)$ & Area $\left(\mathrm{Km}^{2}\right)$ & Area $(\%)$ \\
\hline Highly suitable $\left(\mathrm{SI}_{1}\right)$ & 419.07 & 8.83 & 75.11 & 1.58 & 87.75 & 9 & 4391.82 & 92 \\
\hline Moderately suitable $\left(\mathrm{SI}_{2}\right)$ & 771.27 & 16.25 & 308.09 & 6.49 & 413.94 & 11 & 331.17 & 7 \\
\hline Marginally suitable $\left(\mathrm{SI}_{3}\right)$ & 3012.48 & 63.46 & 4199.17 & 88.46 & 4004.12 & 13 & 24.00 & 1 \\
\hline Not suitable $(\mathrm{N})$ & 544.17 & 11.46 & 164.62 & 3.47 & 133.76 & 67 & 0 & 0 \\
\hline
\end{tabular}


Table 8. Ranking the high suitable land

\begin{tabular}{|c|c|c|c|}
\hline & High suitable area $\left(\mathrm{km}^{2}\right)$ & $\begin{array}{c}\text { Percentage of high suitable area } \\
\text { per currently field rice crop }\end{array}$ & $\begin{array}{c}\text { Rank focus on coverage of large } \\
\text { area suitable }\end{array}$ \\
\hline $\mathrm{A}_{8}$ (Trieu Phong district) & 63.14 & 69.13 & 1 \\
\hline $\mathrm{A}_{9}$ (Hai Lang district) & 56.87 & 53.49 & 3 \\
\hline $\mathrm{A}_{3}$ (Vinh Linh district) & 29.80 & 16.18 & 4 \\
\hline $\mathrm{A}_{5}$ (Gio Linh district) & 16.38 & 18.36 & 5 \\
\hline $\mathrm{A}_{7}$ (Cam Lo district) & 14.72 & 19.66 & 6 \\
\hline $\mathrm{A}_{2}$ (Quang Tri town) & 7.08 & 78.63 & 7 \\
\hline $\mathrm{A}_{2}$ (Dong Ha city) & 6.05 & 26.96 & 8 \\
\hline $\mathrm{A}_{6}$ (Dakrong district) & 1.04 & 2.55 & 9 \\
\hline $\mathrm{A}_{4}$ (Huong Hoa district) & 0.10 & 0.14 & 10 \\
\hline $\mathrm{A}_{10}$ (Con Co district) & 0 & 0.00 & 2 \\
\hline
\end{tabular}
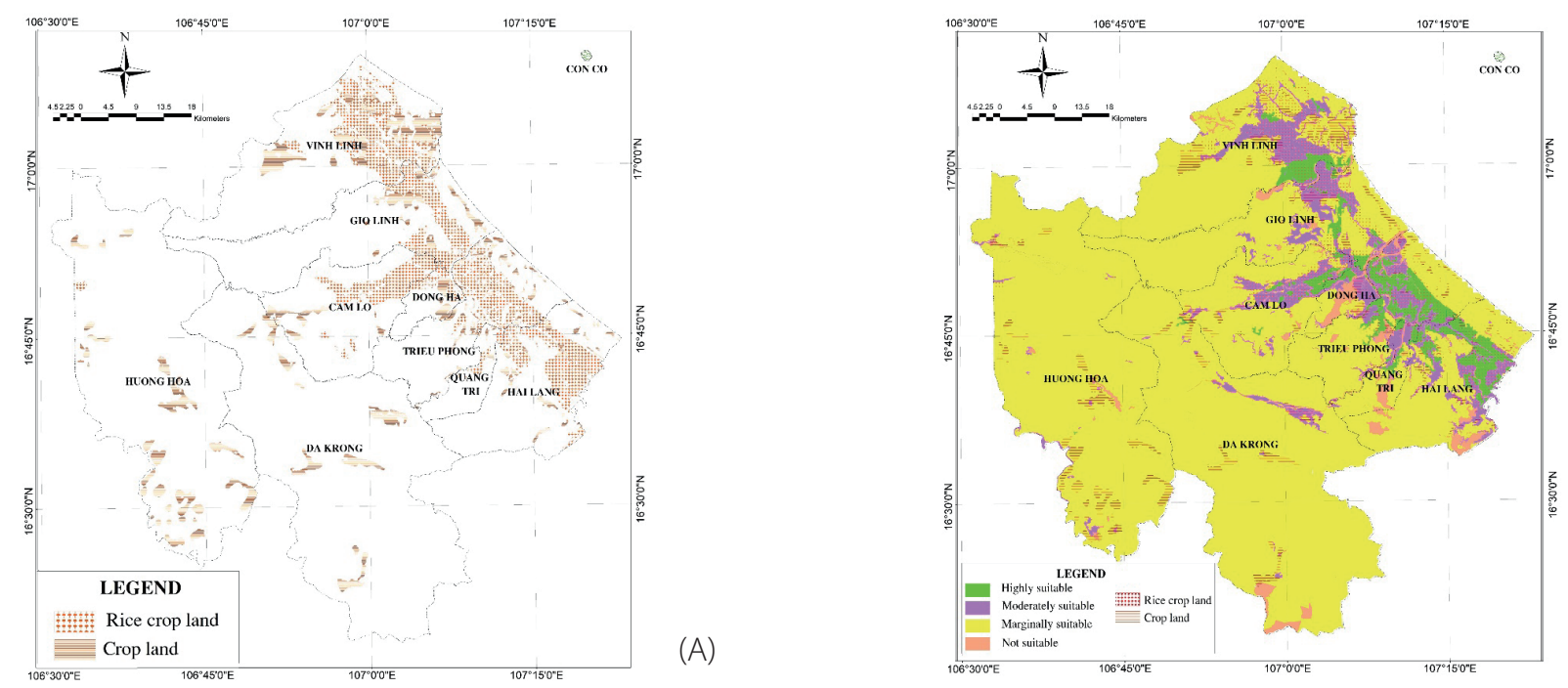

Fig. 4. (A) The actual currently rice fields and other crops land; (B) Land suitable area for rice crop

For rice crops, the results of the pairwise comparisons revealed that hydrological criteria $(0.408)$ has the greatest weighting followed by soil (0.399), topography $(0,104)$, and climate (0.089) in order of importance (Table 6). There were a number of important factors to consider, including soil, topographic, and hydrological requirements. The hydrological criterion and irrigation conditions were the only two to receive significant attention, whereas the average annual rainfall appeared to take the least attention. The soil types and soil texture have the largest and lowest weights, respectively, among the overall soil sub-criteria. Additionally, the number of sunshine hours per month was the most important climatic sub-criteria to consider when describing land suitability for rice crop production among the climatic sub-criteria. Out of the four main criteria, there was a consistency ratio (CR) of 0.005 for the matrix. Once it related to soil, topographic, hydrological, and climatic conditions, the correlation coefficient values (CR) were 0.0058, 0.0027, 0.032, 0.0001, respectively. This demonstrated the accuracy of the matrix result are mentioned in (Table 6). Due to the fact that their threshold values were on the narrow side for rice crops, hydrological criteria (2\% of the province's total area) and topographical criteria ( $9 \%$ of the province's total area) restrict the amount of appropriate land for rice crop production (Table 7, Fig. 3). It has been shown that irrigation conditions and soil type have a stronger influence on rice crop development than any of the other variables involved. It was discovered that $28.3 \%\left(192.49 \mathrm{~km}^{2}\right)$ of the total field area in the study province was very favourable to the production of rice. The districts of Trieu Phong, Hai Lang, Vinh Linh, and Gio Linh had the largest appropriate land areas with areas of a very suitable index, $63.14 \mathrm{~km}^{2}, 56.84 \mathrm{~km}^{2}, 29.8 \mathrm{~km}^{2}$, and $16.38 \mathrm{~km}^{2}$ in area, respectively (Table 8, Fig. 4). Kihoro, (2013) carried out a research work in Kenya's Kirinyaga, Embu, and Mberee counties with a special emphasis on biophysical characteristics such as soil, climate, and terrain, which were taken into account for suitability analysis. In this study, topography and soil texture were 2 criteria that had the highest weight. Hydrology is what they are not took into consideration. Meanwhile, we consider that hydrology is the most essential option to address (highest weight). In Vietnam, the irrigation system remains underdeveloped and has not been modernised, the state of the irrigation system has an effect on rice production in the province. Some other studies on the evaluation of suitable potential areas for agricultural activities in the semi-arid terrestrial ecosystem in the Central Anatolia Region, terrain properties and soil features also were used to identify sites suitable for agriculture lands, the authors used both physical and chemical factors of soil to evaluate soil nutrition and soil quality index (Sezer et al 2014, Özkan 
et al 2020, Seyedmohammadi 2019, Rath et al 2018). The information was gathered through a variety of methods, including literature reviews, a structure-questionnaire, focus group discussions with local stakeholders, and individual interviews, all of which were conducted using the techniques of Participatory Rapid Appraisal and conceptual content analysis to gather the information. As a consequence, the diagnostic criteria for sustainable land management were developed in accordance with the framework for assessing sustainable land management, and they are as follows: productivity, security, protection, viability, and acceptability (Rath et al 2018). It is possible to apply and assess the sustainability indicators identified in these study in rice crop production regions of our study, which might result in the development of a strategic plan and increased sustainability in the future. Seyedmohammadi (2019) developed a similar model using the soil physical criteria. But erosion degree criteria were used instead of hydrology criteria. In high elevations, the source of erosion is rainfall; however, in lower elevations, the source of erosion is the river and creeks. Thus, the selection factors for evaluation are quite diverse. However, farmers are the most important people who have an understanding of their work. As a result, the findings of this study reflect cultural farming, with locals focusing on such criteria when deciding where to farm.

\section{CONCLUSIONS}

This study aimed to identify the high-suitable areas for rice-crops cultivation in terms of multiple potential factors by experts' opinions. Results show that soil irrigation conditions and soil type are the most important factor influencing the suitable index of land, followed by slope, and then the number of sunny hours per month. Hai Lang and Trieu Phong districts are ostensibly the worst sites because they are nearest to the negative ideal solution and it is of necessity to pay increased attention to varying purposes of using rice crop lands in Cam Lo, Quang Tri, Dong $\mathrm{Ha}$, Dakrong, Huong Hoa, Con Co districts. These study revealed that the AHP and TOPSIS techniques arrived at identical predictions of land potential for rice cultivation, with a particular emphasis on four districts in the highest echelon of the rankings. Our results validated previously reports from the Ministry of Agriculture and Rural Development of Vietnam that Hai Lang and Trieu Phong were linked to the greatest agricultural areas in the province of Quang Tri, which resulted in the best rice crop output in the province. Within the study area, the land suitability evaluation is considered now as a vital link to sustainability of society, regarding productivity and environmental stability. Study reveals that integration of multi-criteria analysis (AHP and TOPSIS) has been used as an effective method of supporting the administration decision-makers who could base on ranked decision to decide on the planning of agricultural programs with environmental, economic and social sustainability.

\section{REFERENCES}

Akıncı H., Özalp A.Y., Turgut B. (2013). Agricultural land use suitability analysis using GIS and AHP technique. Computers and electronics in agriculture, 97, 71-82.

Al-Yamani W., Kennedy S., Sgouridis S., Yousef L.F. (2013). A land suitability study for the sustainable cultivation of the halophyte Salicornia bigelovii: the case of Abu Dhabi, UAE. Arid land research and management, 27(4), 349-360.

Bagheri M., Sulaiman W.N.A. Vaghefi N. (2013). Application of geographic information system technique and analytical hierarchy process model for land-use suitability analysis on coastal area. Journal of coastal conservation, 17(1), 1-10.

Bozdağ A., Yavuz F., Günay A.S. (2016). AHP and GIS based land suitability analysis for Cihanbeyli (Turkey) County. Environmental Earth Sciences, 75(9), 813.

Chau T.T.M., Chuong H.V., Phuong T.T. (2017). Mapping mapping of dangerous zone distribution on rice land based on the hydraulic standard indicator in hoa vang district, Da Nang city. Journal of Agricultural Science and Technology, 1(1), 17-26. (Vietnamese).

Dengiz O. (2013). Land suitability assessment for rice cultivation based on GIS modeling. Turkish Journal of Agriculture and Forestry, 37(3), 326-334.

Dieu N.T. (2017). Research on drought situation in summer-autumn rice cultivation by remote sensing technology and GIS in Dai Loc district, quang nam province. journal of science, Hue university. Journal of Social Sciences, Humanities and Education, 7(1), 1-8. (Vietnamese).

Estrada L.L., Rasche L., Schneider U.A. (2017). Modeling land suitability for Coffea arabica L. in Central America. Environmental Modelling \& Software, 95, 196-209.

FAO (1983). Guidelines. Land Evaluation for Rainfed Agriculture. FAO Soils Bulletin No, 52, Rome.

FAO (1985). Guidelines. Land Evaluation for Irrigated Agriculture. FAO Soils Bulletin No, 55, Rome.

FAO (1993). FESLM: An international framework for evaluating sustainable land management. World soil resources report 73. FAO, Rome, Italy.

FAO (1976). A framework for land evaluation, Soil Bulletin 32. Food and agriculture organization of the United Nations, Rome.

Hummel J.M., Bridges J.F., IJzerman M.J. (2014). Group decision making with the analytic hierarchy process in benefit-risk assessment: a tutorial. The Patient-Patient-Centered Outcomes Research, 7(2), 129-140.

Huynh V.C., Nguyen H.K.L., Pham G.T., Tran T.P., Duong Q.N., Le. D.P. (2015). Research on drought situation in summer-autumn rice cultivation by remote sensing technology and GIS in Dai Loc district, Quang Nam province. Journal of Science, Hue University, 4(103). (Vietnamese).

Jamil M., Ahmed R., Sajjad H. (2018). Land suitability assessment for sugarcane cultivation in Bijnor district, India using geographic information system and fuzzy analytical hierarchy process. GeoJournal, 83(3), 595-611.

Kazemi H., Sadeghi S., Akinci H. (2016). Developing a land evaluation model for faba bean cultivation using geographic information system and multi-criteria analysis (A case study: Gonbad-Kavous region, Iran). Ecological Indicators, 63, 37-47.

Keisler J.M. (2008). The value of assessing weights in multi-criteria portfolio decision analysis. Journal of Multi-Criteria Decision Analysis, 15(5-6), 111-123.

Kihoro J., Bosco N.J., Murage H. (2013). Suitability analysis for rice growing sites using a multicriteria evaluation and GIS approach in great Mwea region, Kenya. SpringerPlus, 2(1), 1-9.

Malczewski J. (1999). GIS and multicriteria decision analysis. New York. Wiley. 
Maleki F., Kazemi H., Siahmarguee A., Kamkar B. (2017). Development of a land use suitability model for saffron (Crocus sativus L.) cultivation by multi-criteria evaluation and spatial analysis. Ecological Engineering, 106, 140-153.

Ministry of Science and Technology of Vietnam. (2012). Instruction for agricultural production land evaluation of National Standard ISO 8409: 2012

Özkan B., Dengiz O., Turan, I.D. (2020). Site suitability analysis for potential agricultural land with spatial fuzzy multi-criteria decision analysis in regional scale under semi-arid terrestrial ecosystem. Scientific Reports, 10(1), 1-18.

Quang Tri Provincial Committee (2020). Socio-economic summary report.

Quang Tri Statistical Office. (2019). Statistical Yearbook, Statistical Publishing House.

Rahmanipour F., Marzaioli R., Bahrami H.A., Fereidouni Z., Bandarabadi S.R. (2014). Assessment of soil quality indices in agricultural lands of Qazvin Province, Iran. Ecological indicators, 40, 19-26.

Rath S.S., Panda J., Annadurai R., Nanda S. (2018). A Study on Land Suitability for Rice Cultivation in Khordha District of Odisha (India) Using Remote Sensing and GIS. Earth Systems and Environment, 2(1), 119-132.

Saardchom N. (2012). The validation of analytic hierarchy process (AHP) scoring model. International Journal of Liability and Scientific Enquiry, 5(2), 163-179.

Saaty T.L. (2000). Fundamentals of decision making and priority theory with the analytic hierarchy process. RWS Publications, Pittsburg. Saaty T.L. (2008). Decision making with the analytic hierarchy process. International journal of services sciences, 1(1), 83-98.

Seyedmohammadi J., Sarmadian F., Jafarzadeh A.A., McDowell. R.W. (2019). Development of a model using matter element, AHP and GIS techniques to assess the suitability of land for agriculture. Geoderma, 352, 80-95.

Sezer I., Dengiz, O. (2014). Application of a multicriteria decision-making approach for rice land suitability analysis in Turkey. Turkish Journal of Agriculture and Forestry, 38(6), 926-934.

Stefanidis S., Stathis D. (2013). Assessment of flood hazard based on natural and anthropogenic factors using analytic hierarchy process (AHP). Natural hazards, 68(2), 569-585.

Suder A., Kahraman C. (2018). Multiattribute evaluation of organic and inorganic agricultural food investments using fuzzy TOPSIS. Technological and Economic Development of Economy, 24(3), 844-858.

Tang J., Wang C., Lin N., Li Z., Li H., Mao, Z. (2009). Application of matter-element model in soil nutrient evaluation of ecological fragile region. Chinese Geographical Science, 19(2), 168-176.

Vy N.D. (2014). Results of research and application of GIS technology and remote sensing technology to management of rice production in the Cuu Long river delta. Journal of Irrigation Science and Technology, 20, 1-12. (In Vietnamese).

Waqar M.M., Rehman, F., Ikram, M. (2013, July). Land suitability assessment for rice crop using geospatial techniques. In 2013 IEEE International Geoscience and Remote Sensing Symposium-IGARSS ( 2844-2847).

IEEE.Zadeh L.A. (1965). Information and control. Fuzzy sets, 8(3), 338-353.

Zhang J., Su Y., Wu J., Liang H. (2015). GIS based land suitability assessment for tobacco production using AHP and fuzzy set in Shandong province of China. Computers and Electronics in Agriculture, 114, 202-211. 